\title{
SIKAP DAN PANDANGAN ORANG-ORANG YAHUDI TERHADAP ISLAM
}

\author{
Saidurrahman \\ Institut Agama Islam Negeri (IAIN) Sumatera Utara \\ e-mail:saidurrahman@yahoo.com
}

\begin{abstract}
This article discusses on the attitude of the Jews who claim to be the chosen peoples ourced from theological doctrine handed down from one generation to the next. Although existentially Jews acknowledge other nations, butitwas limited to there cognition of their existence, not on fundamental rights possessed. With that understanding, attitude and outlook superior to the other nations causing them easily perform a variety of cruelacts beyond the limits of humanity. History has recorded that the relationship between Muslims with Jews alwaystingedtensions for the sake of suspense. Of course, the tensionsarising from unfair attitude that made the Jews in many aspects. Al-Quran and Hadith following historical facts, as the main source of this article, informing us that the attitudes of the Jews against Muslimstend pejorative other than brutal. Criticism for the sake of criticism and even physical violence often they are addressed to Muslims. It happensin everytime and opportunity, not only at the time of the apostles before the Prophet Muhammad, on his future until the time we were the attitude of the Jewish people never change.
\end{abstract}

Abstrak: Artikel membahas tentang sikap orang-orang Yahudi yang mengklaim sebagai bangsa pilihan bersumber dari doktrin teologis yang diwariskan dari satu generasi ke generasi berikutnya. Meskipun secara eksistensial orang-orang Yahudi mengakui bangsa-bangsa lain, namun pengakuan itu hanya sebatas pada keberadaan mereka, bukan pada hak-hak dasar yang dimiliki. Dengan pemahaman itu, sikap dan pandangan lebih superior dibanding dengan bangsa-bangsa lain menyebabkan mereka mudah melakukan berbagai tindakan kejam di luar batas peri kemanusiaan.Sejarah telah merekam bahwa hubungan antara kaum Muslimin dengan orang-orang Yahudi selalu diwarnai ketegangan demi ketegangan.Tentu saja, ketegangan itu muncul akibat sikap 
SAIDURRAHMAN: Sikap dan Pandangan Orang-orang Yahudi

tidak fair yang dilakukan orang-orang Yahudi dalam banyak aspek.Al-Quran dan hadis berikut fakta sejarah, sebagai sumber utama dalam tulisan ini, menginformasikan kepada kita bahwa sikap dan pandangan orang-orang Yahudi terhadap umat Islam cenderung peyoratif selain brutal.Kecaman demi kecaman bahkan kekerasan fisik kerap mereka tujukan kepada umat Islam.Hal itu terjadi dalam setiap waktu dan kesempatan, tidak hanya pada masa rasul-rasul sebelum Rasulullah Muhammad saw, pada masa beliau hingga masa kita pun sikap orang-orang Yahudi tidak pernah berubah.

Keywords: Yahudi, Taurat, al-Quran, Zionisme, Nabi Muhammad.

\section{A. Pendahuluan}

Dalam tradisi agama Ibrahim (Yahudi, Kristen dan Islam), ${ }^{1}$ Yahudi dikenal sebagai agama yang tertua.Ketiga agama ini berasal dari nenek moyang serumpun dan dikelompokkan sebagai agama samawi. Karena berasal dari geneologi yang sama, mestinya ketiga agama tersebut (utamanya Yahudi) dapat membangun harmoni sosial dengan agama lainnya. Pada kenyataannya tidak demikian, sejarah banyak merekam lahirnya nestapa kemanusiaan justru dilahirkan oleh penganut agama samawi tertua itu.Mulai dari pemberontakan teologis sampai pembunuhan besar-besaran terhadap anak manusia kerap dilakukan orang-orang Yahudi. Tindakan tersebut tidak terbatas dalam kaca mata sejarah saja, di dunia modern seperti sekarang sekalipun, sikap dan pandangan mereka hampir tidak terjamah perubahan.Tentu saja, salah satu objek yang kerap dijadikan target penghancuran itu adalah umat Islam.Di hadapan orang-orang Yahudi, harga sebuah nyawa tidak lebih daripada seonggok bangkai yang segera harus dibersihkan. Jeritan dan tangisan pilu di ladang pembantaian (the killing field) yang santer terdengar, bagi mereka ibarat permainan yang cukup mengasyikkan. Terkait dengan ini, penulisakan menguraikan pandangan dan sikap orang-orang Yahudi terhadap Islam. Dengan 
menggunakan al-Quran dan hadis sebagai landasannya,penulis jugaakan melihatnya dari perspektif sejarah, kenyataan-kenyataan di dunia modern juga akan diuraikan.

\section{B. Sejarah Singkat Yahudi}

Yahudi adalah agama samawi (yang berdasarkan wahyu dari Allah).Agama ini ada sekitar 2000 tahun sebelum agama Islam turun.Kitab sucinya adalah at-Taurat yang diturunkan kepada Nabi Musa. ${ }^{2}$ Ada beberapa pendapat mengenai asal kata Yahudi, diantaranya yang paling mendekati kebenaran adalah bahwa kata yahūd diambil dari kata hāda-yahūdu yang berarti raja'a- yarji'u (kembali). ${ }^{3}$ Makna ini diperkuat oleh QS.al-A'raf [7]: 156, "Innā hudnā ilak, artinya sesungguhnya aku (Musa) telah kembali kepadamu."Ayat ini menjelaskan bahwa kedatangan Nabi Musa.kepada kaumnya untuk mengembalikan mereka ke jalan yang benar.

Ada beberapa nama lain untuk kaum Yahudi, diantaranya, Banī Israīl, al-'ibriyyūn/al-'ibrāniyyūn, Qaum Musa (pengikut Musa), dan Ahl al-Kitāb. ${ }^{4}$ Nama-nama inilah yang sering dipakai oleh al-Quran untuk menyebut mereka. Hal ini dapat dilihat misalnya dalam QS.alBaqarah [2]: 43, 67, 83, 120; al-Mā'idah [5]: 51;Ali-'Imran [3]: 64;alA'rāf [7]: 156.Pada awalnya orang-orang Yahudimerupakan pengikut Nabi Musa.Mereka merupakan pengikut yang baik, karena mengikuti ajaran-ajaran yang disampaikan oleh Nabi Musa. Namun, setelah Nabi Musa wafat mereka banyak melakukan tahrïf(mengubah isi) Taurat dan banyak melakukan pelanggaran pada ajaran-ajaran mereka.

\section{Doktrin Bangsa Pilihan}

Salah satu doktrin yang terdapat dalam agama Yahudi adalah sebuah keyakinan bahwa mereka merupakan bangsa pilihan (the chosen people). Pada mulanya doktrin ini memberikan pemahaman yang baik. Dengan kata lain, bangsa pilihan itu menyatakan bahwa 
SAIDURRAHMAN: Sikap dan Pandangan Orang-orang Yahudi

mereka dipilih Tuhan untuk melaksanakan perintah-perintah Tuhan di muka bumi. Selain itu, orang-orang Yahudi juga mempunyai tanggung jawab moral yang teramat besar untuk menyampaikan ajaran-ajaran kebaikan kepada semua manusia. ${ }^{5}$ Mereka merupakan para pendeta dan para pendidik dari kebenaran agama universal. ${ }^{6}$ Dalam perjalanannya, secara politis, doktrin itu dipahami secara keliru sebagai sebuah doktrin yang eksklusif. Kekeliruan tersebut terletak pada sebuah pemahaman bahwa bangsa Yahudi merupakan bangsa yang dipilih Tuhan untuk memimpin seluruh umat manusia dan menguasai alam semesta. Tentu saja, seiring dengan perjalanan waktu, doktrin itu berubah menjadi sebuah legitimasi teologis dalam sikap dan pandangan orang-orang Yahudi terhadap bangsa-bangsa lain. Tahun 1973, Yakov Malik, Utusan Uni Sovyet untuk PBB berkomentar,

"The Zionist have come forward with the theory of the Chosen People, an absurd ideology. That is religious racism.

Para zionis memunculkan teori bangsa pilihan, sebuah teori yang tidak masuk akal. Rasisme religius."

Selanjutnya Malik menekankan, "In deed, the most demaging anti-Semitic document in history, the forgery known as The Protocols of the Elders of Zion, is based on the idea of international conspiracy to rule the world by "the Chosen People/Dalam sejarah, dokumen tentang antisemitik yang paling mengerikan adalah sebuah naskah yang dikenal dengan The Protocols of the Elders of Zion, yang menyatakan bahwa dunia harus dikendalikan oleh "Bangsa Pilihan (baca: orangorang Yahudi)"7

Dapat diduga, melalui legitimasi teologis yang diwariskan dari generasi ke generasi, doktrin bangsa pilihan itu mereka rasakan sebagai keutamaan dan kelebihan mereka atas bangsa-bangsa lain. Meskipun secara eksistensial orang-orang Yahudi mengakui bangsabangsa lain, namun pengakuan itu hanya sebatas pada keberadaan mereka, bukan pada hak-hak dasar yang dimiliki. Dengan 
pemahaman itu, sikap dan pandangan lebih superior dibanding dengan bangsa-bangsa lain menyebabkan mereka mudah melakukan berbagai tindakan kejam di luar batas peri kemanusiaan.

\section{Beberapa Karakteristik Orang-Orang Yahudi}

Al-Quran banyak merekam karakteristik orang-orang Yahudi ini. Di antara karakteristik orang-orang Yahudi yang dijelaskan alQuran terkait dengan aspek akidah dan relasi sosial. Namun bukan berarti karakteristik orang-orang Yahudi pada aspek-aspek lain tidak penting. Hal ini hanya merupakan sebuah prioritas, mengingat aspek akidah dan relasi sosial amat penting diperbincangkan.

\section{Karakteristik Yahudi dalam AspekAkidah}

Orang-orang Yahudi banyak menyelewengkan ajaran yang telah mereka dapatkan dari Nabi Musa As. Dalam al-Quran, QS.atTaubah [9]: 30, dijelaskan bahwaorang-orang Yahudi berkata: "'Uzair itu putera Allah" dan orang-orang Nasrani berkata: "Al-Masih itu putera Allah." Demikianlah, itu ucapan mereka dengan lisan mereka sendiri.Mereka sebenarnya meniru perkataan orang-orang kafir yang terdahulu. Dari ayat ini nampak jelas bahwa orang-orang Yahudi telah menghina Allah, karena telah menyamakan Allah dengan makhluk-Nya. Padahal Allah SWT tidak beranak dan juga tidak diperanakkan. Al-Quran membantah kekeliruan orang-orang Yahudi tersebut.Bantahan Allah ini ditegaskan dalam QS.al-Ikhlas [112]: 3: "Dia tiada beranak dan tiada pula diperanakkan."Terkait dengan 'Uzair sebagai putera Allah, dalam Tafsīral-Marāghī dijelaskan bahwa ia adalah seorang pendeta (kāhin) Yahudi yang hidup sekitar 457 SM. Menurut kepercayaan orang-orang Yahudi 'Uzair adalah orang yang telah mengumpulkan kembali wahyuwahyu Allah di kitab at Taurat yang sudah hilang sebelum masa Nabi Sulaiman As. Sehingga segala sumber yang dijadikan rujukan utama adalah yang berasal dari 'Uzair.Menurut kaum Yahudi waktu itu 
SAIDURRAHMAN: Sikap dan Pandangan Orang-orang Yahudi

'Uzair adalah satu-satunya sosok yang paling diagungkan, maka sebagian mereka akhirnya menisbatkan 'Uzair sebagai anak Allah. ${ }^{8}$

Dari perspektif Islam penyelewengan dalam masalah akidah merupakan kekeliruan yang amat besar.Sekitar 1/3 dari kandungan al-Quran menjelaskan tentang akidah/kepercayaan atas semua rukun iman yang harus diyakini oleh setiap manusia.Besarnya persentasi ayat-ayat keimanan itu merupakan bukti bahwa aspek keislaman yang satu ini menempati posisi yang amat signifikan. Dengan demikian amatlah tepat jika al-Quran banyak mengulasnya. Sementara dalam ayat lain Allah juga menjelaskan bahwa orangorang Yahudi selalu mengungkapkan sesuatu yang bersifat peyoratif tentang Allah. Lihat misalnya padaayat berikut ini,di dalamnya dijelaskan bahwaorang-orang Yahudi berkata:

"Tangan Allah terbelenggu", sebenarnya tangan merekalah yang dibelenggu ${ }^{9}$ dan merekalah yang dila'nat disebabkan apa yang telah mereka katakan itu. (Tidak demikian), tetapi kedua-dua tangan Allah terbuka; Dia menafkahkan sebagaimana Dia kehendaki. Dan al-Quran yang diturunkan kepadamu dari Tuhanmu sungguh-sungguh akan menambah kedurhakaan dan kekafiran bagi kebanyakan di antara mereka. Dan Kami telah timbulkan permusuhan dan kebencian di antara mereka sampai hari kiamat.Setiap mereka menyalakan api peperangan Allah memadamkannya dan mereka berbuat kerusakan dimuka bumi dan Allah tidak menyukai orang-orang yang membuat kerusakan."10

Ayat ini dengan jelas menguraikan penghinaan orang-orang Yahudi terhadap keesaan Allah itu. Mereka mengatakan bahwa tangan (kekuasaan) Allah telah terbelenggu (dari kebaikan).Mereka menganggap Allah bakhil. Padahal tangan mereka yang sebenarnya terbelenggu dari kebaikan dan mereka lebih menyukai kebakhilan. Mereka tidak bersyukur kepada Allah atas segala nikmat yang telah diberikan kepada mereka, tetapi justru mereka selalu kufur nikmat. ${ }^{11}$ 


\section{Karakteristik Yahudi dalam Aspek Sosial}

Ada satu topik dalam aspek sosial yang diangkat dalam ayat berikut:"Di antara Ahli kitab ada orang yang jika kamu mempercayakan kepadanya harta yang banyak, dikembalikannya kepadamu; dan di antara mereka ada orang yang jika kamu mempercayakan kepadanya satu dinar, tidak dikembalikannya kepadamu kecuali jika kamu selalu menagihnya. Yang demikian itu lantaran mereka mengatakan: 'tidak ada dosa bagi kami terhadap orang-orang ummi.'12Mereka berkata dusta terhadap Allah, padahal mereka mengetahui."13

Allah telah menjelaskan sikap mereka yang sulit untuk bisa dipercaya, sebagaimana sifat orang munafik yang suka berbohong, khianat, dan ingkar janji. Selain itu mereka juga suka meremehkan kaum lain, seperti sikap Yahudi kepada bangsa Arab, pendapat ini diambil dari penafsiran yang menjelaskan maksud kata al-ummiyyīn adalah orang-orang arab. Dari Ayat ini kita bisa mengambil pelajaran yang sangat berarti yaitu untuk lebih berhati-hati dalam bermuamalah dengan mereka baik yang bersifat politik atau hubungan sosial lainnya. Tentu saja kehati-hatian itu dimaksudkan agar kita bisa selamat dari tipu daya mereka.

Secara umum manusia memiliki karakteristik untuk berbuat semena-mena, karena merasa paling hebat dan kuat, serta sombong. Begitu juga karakteristik yang dimiliki kaum Yahudi.Mereka suka membuat kerusakan di muka bumi dengan melakukan perang dan sejenisnya. Jika kita mengaitkan dan menganalisakembali QS.alMā'idah [5]: 64 pada poin 1 (baca: sebagai diskursus akidah), Allah menjelaskan bahwa orang-orang Yahudi akan selalu berbuat kerusakan di muka bumi.Dalam ayat ini digunakan fi'il mudari' pada kata yas'auna, dalam ilmu balaghah penggunaan kalimat yang berbentuk muḍari' memiliki arti istimrār (terus-menerus/ berkelanjutan). Orang-orang Yahudi termasuk golongan yang suka membangkang perintah Allah. Apalagi terhadap ajakan kebaikan dari 
SAIDURRAHMAN: Sikap dan Pandangan Orang-orang Yahudi

sesama manusia, pasti mereka lebih berani untuk menolak. Sekarang kita bisa melihat dengan mata kepala kita sendiri atas sikap mereka yang sudah tidak manusiawi. Dengan berdalih membela diri, tanpa merasa berdosa mereka telah membunuh lebih dari 1300 orang dan telah melukai lebih dari 3000 warga sipil Palestina yang tak berdosa. Resolusi PBB untuk gencatan senjata telah mereka abaikan, demonstrasi dari jutaan manusia di seluruh penjuru dunia juga tidak didengarkan. Sungguh hati dan mata serta telinga mereka telah terkunci oleh kekufuran, sehingga mereka tak pernah menerima kebenaran walau mereka sebenarnya tahu jika mereka bersalah. Di sini semakin jelas terkuak salah satu sifat mereka yang ambigu. Mereka kerapkali melakukan kerusakan dimuka bumi, tetapi mereka tidak mengakui aktivitas mereka itu dan selalu berdalih bahwa yang dilakukannya tetap berada pada koridor kebaikan.

\section{E. Sikap dan Pandangan Orang-Orang Yahudi terhadap Umat Islam}

Ketika kita kembali mengingat sejarah orang-orang Yahudi yang suka membantah ajakan Nabi Muhammad Saw menuju jalan yang benar, maka kita bisa melihat betapa angkuh dan kerasnya hati mereka. Sikap mereka dalam membenci umat Islam tak akan pernah surut sampai kapan pun. Mereka tak akan pernah rela kepada umat Islam, sampai umat Islam mau mengikuti hawa nafsu mereka. Untuk hal ini, Allah memberikan pedoman tegas:

"Dan orang-orang Yahudi dan Nasrani tidak akan rela14 kepadamu (Muhammad) sebelum engkau mengikuti agama mereka..."15

Memang musuh Islam banyak (tak hanya Yahudi), bahkan orang yang beragama Islam yang munafik kepada agama Islam bisa menjadi musuh Islam juga. Namun, rasa permusuhan yang ada dalam hati orang-orang Yahudi lebih keras dan sadis dibanding dengan musuh-musuh yang lain. Allah berfirman: 
Sesungguhnya kamu dapati orang-orang yang paling keras permusuhannya terhadap orang-orang yang beriman ialah orang-orang Yahudi dan orang-orang musyrik. Dan sesungguhnya kamu dapati yang paling dekat persahabatannya dengan orang-orang yang beriman ialah orang-orang yang berkata: "Sesungguhnya kami ini orang Nasrani." Yang demikian itu disebabkan karena di antara mereka itu (orang-orang Nasrani) terdapat pendeta-pendeta dan rahib-rahib, (juga) karena sesungguhnya mereka tidak menyombongkan diri. 16

Dalam Tafsìr al-Alūsi dijelaskan bahwa orang-orang Yahudi disifati oleh Allah sebagai asyaddannās, karena kekufuran mereka yang sudah sangat berlebihan, serta kebiasaan mereka berbohong dan mengikuti hawa nafsu. Bahkan dikatakan juga bahwa dalam pandangan mereka wajib memerangi orang-orang yang menegasikan keinginan mereka. Selain orang Yahudi, orang-orang musyrik juga merupakan musuh yang sangat keras bagi umat Islam. Mengapa berita tentang orang-orang Yahudi disebutkan terlebih dahulu daripada orang-orang Musyrik? Masih menurut al-Imām alAlūsi, dalam tafsirnyadijelaskan bahwa orang-orang Yahudi disebut terlebih dahulu karena kebiasaan mereka yang lebih suka menciptakan permusuhan terlebih dahulu/mencari masalah. Orangorang Yahudi juga selalu mencederai beragam perjanjian yang dibuat kepada mereka sebagaimana akan diuraikan nanti. Sementara ituada yangberpendapat bahwa kejelekannya lebih banyak dari pada yang lain.

Kita semua bisa melihat fakta kebencian mereka terhadap orang-orang Islam yang ada di Gaza, walaupun perang yang berlangsung bukan atas nama agama, tetapi secara otomatis umat Islam, bahkan masyarakat sedunia, merasa ikut diperangi, karena melihat saudara-saudara mereka seagama telah dibantai di Gaza. Tragedi kemanusiaan telah diciptakan oleh orang-orang Yahudi. Mereka ingin menuliskan sejarah dengan darah dan air mata rakyat 
SAIDURRAHMAN: Sikap dan Pandangan Orang-orang Yahudi

Palestina. Sebuah lukisan yang oleh manusia modern disebut dengan genocide.

Bertahun-tahun Yahudi Israel menjajah, mengusir dan menyiksa rakyat Palestina. Berbagai macam kecaman telah mereka dapatkan dari mayoritas manusia di seluruh penjuru dunia, Ratusan ribu orang berdemonstrasi di negara-negara Eropa, puluhan ribu orang berdemonstrasi di negara-negara Arab dan Asia Tenggara untuk mengecam agresi militer, tetapi mereka justru semakin gila meluncurkan serangan-serangan ke pemukiman warga Gaza. Yahudi Israel benar-benar telah melanggar HAM.Mereka juga telah melakukan kejahatan perang dengan menghancurkan tempattempat ibadah, sekolahan, kantor-kantor media massa, membunuh anak-anak serta membantai warga sipil. Israel menuduh Hamas sebagai kelompok teroris yang harus dihancurkan.Padahal Israel sebenarnya yang lebih pantas disebut teroris. ${ }^{17}$ Sungguh sikap mereka sangat keji dan tidak manusiawi. Kita masih belum tahu sampai kapan mereka akan menghentikan kebiadaban mereka, apakah menunggu siksaan Allah yang akan segera datang untuk balasan bagi orang-orang yang zalim seperti mereka?

Untuk itu, lembaran-lembaran sejarah hitam Yahudi tidak boleh diabaikan. Sebab dengan lembaran-lembaran hitam itu kita dapat memetakan bagaimana karakteristik orang-orang Yahudi yang sebenarnya, terutama sikap mereka selama bergaul dengan umat Islam. Berikut ini akan penulis jelaskan sikap-sikap umat Yahudi tersebut dalam perspektif historis. ${ }^{18}$ Perspektif historis ini penulis munculkan dengan alasan agar kita bisa menjadikan sikap-sikap tersebut sebagai pelajaran berharga dalam memotret jati diri orangorang Yahudi yang sesungguhnya.

\section{Mengadu Domba antara Suku Aus dan Khazraj dari Kalangan Anșār}

Ibn Ishāq meriwayatkan bahwa Syas bin Qais adalah seorang tokoh Yahudi yang sudah tua renta dan sekaligus pencipta 
kekufuran. Dia sangat membenci dan mendengki orang muslim. Suatu kali dia melewati beberapa orang shahabat dari Aus dan Khazraj yang sedang berkumpul dan berbincang-bincang dalam suatu majelis. Melihat hal itu dia berkata kepada seorang pemuda Yahudi, "Hampirilah orang-orang itu dan duduklah bersama mereka. Kemudian ungkit kembali perang bu'ats yang pernah mereka alami. Lantunkan kembali syair-syair yang pernah mereka ucapkan secara berbalas-balasan pada saat itu." Pemuda itupun melakukan apa apa yang diperintahkan Syas. Akibatnya mereka saling berdebat dan saling membanggakan diri, hingga ada dua orang yang melompat bangkit dan adu mulut secara sengit. Salah seorang diantara keduanya berkata kepada yang lain "Jika memang kalian menghendaki, saat ini pula kami akan menghidupkan kembali akar peperangan diantara kita." Kedua belah pihak (Aus dan Khazraj) ikut terpancing, lalu masing-masing mengambil senjatanya dan hampir saja terjadi adu fisik. Tetapi Rasulullah pun dengan cepat menghentikan pertikaian ini.

\section{Memberikan Gangguan kepada Orang-Orang Beriman}

Ibnu Hisyam meriwayatkan bahwa ada seorang wanita muslimah yang datang ke pasar Bani Qainuqah (suku Yahudi) sambil mengenakan jilbabnya. Dia duduk di dekat seorang pengrajin perhiasan. Tiba-tiba beberapa orang dari mereka bermaksud menyingkap kain yang menutupi wajahnya. Tentu saja wanita muslimah itu berontak. Diam-diam tanpa diketahui wanita muslimah itu, pengrajin perhiasan tersebut mengikat ujung bajunya, sehingga tatkala bangkit auratnya tersingkap. Merekapun tertawa dibuatnya. Secara spontan wanita muslimah itu berteriak. Seorang laki-laki muslim yang ada di dekatnya melompat ke arah pengrajin perhiasan dan membunuhnya. Orang-orang Yahudi lainnya mengikat laki-laki muslim itu lalu membunuhnya. Dengan alasan itu, Rasulullah kemudian memerangi mereka . 
SAIDURRAHMAN: Sikap dan Pandangan Orang-orang Yahudi

\section{Berencana Membunuh Rasulullah}

Orang-orang Yahudi merencanakan untuk membunuh Rasulullah. Ini terjadi pada saat beliau mendatangi mereka bersama beberapa orang sahabat, agar mereka mau membantu membayar tebusan bagi dua orang dari Bani Amir yang dibunuh Amr bin Umayyah adh-dhamry. "Kami akan membantumu wahai Abul Qasim. Sekarang duduklah disini, biar kami menyiapkan kebutuhanmu," kata orang-orang Yahudi Bani Nadhir. Beliau duduk di pinggir tembok salah satu dari rumah mereka, disamping beliau ada Abu Bakar, Umar, Ali dan beberapa shahabat yang lain. Ketika melihat Rasulullah telah duduk di tempat yang telah ditentukan maka merekapun berunding untuk membunuh Rasulullah dengan cara menjatuhkan batu penggiling dari atas Rasulullah. Ketika orangorang Yahudi hendak merencanakan niat jahat mereka, Jibril turun kepada Rasulullah dan memberitahukan rencana orang-orang Yahudi. Maka seketika itu pula Rasulullah beranjak dari tempat duduknya dan pulang ke Madinah tanpa memberitahu kepada shahabat penyebab kepulangannya. Setelah sampai di Madinah barulah Rasulullah mengabarkan kepada para sahabatnya dan langsung mengutus Muhammad bin Maslamah untuk memberi pengumuman kepada Bani Nadhir agar mereka segera meninggalkan Madinah. Orang-orang Yahudi inipun kembali memperlihatkan ulahnya dan tidak mau meninggalkan Madinah, sehingga Rasulullah pun memerangi mereka.

\section{Menghimpun Seluruh Kekuatan Kafir untuk Me- merangi Islam}

Orang-orang Yahudi adalah orang-orang yang mempunyai mental pengecut, mereka tidak berani melawan Rasulullah hanya dengan kekuatan sendiri.Setelah mengalami penghinaan dengan dikalahkannya mereka pada peperangan sebelumnya, maka Bani Naḍir mencari dukungan dari orang-orang kafir Quraisy, kabilah- 
kabilah di Ghațafan, serta beberapa kabilah Arab yang membenci dakwah Islam.Mereka sepakat untuk menyerang Madinah. Jumlah pasukan mereka jauh melebihi jumlah penduduk kota Madinah termasuk wanita dan anak-anak, sekitar sepuluh ribu prajurit. Perang ini dikenal dengan sebutan perang aḩab. Ketika mendengar hal tersebut, Rasulullah pun menggelar majelis musyawarah dengan para shahabat untuk menyusun strategi menghadapi pasukan multi agama ini. Akhirnya lahir sebuah kesepakatan untuk membuat parit yang mengelilingi kota Madinah. Setelah parit selesai, pasukan kafir ini heran dan bingung karena mereka belum pernah melihat strategi perang seperti ini sebelumnya.Akhirnya merekapun bertahan dengan mendirikan tenda di luar kota madinah. Tidak berapa lama, Allah pun mengirimkan taufannya untuk memporak-porandakan pasukan multi agama ini.

\section{Mengkhianati Perjanjian}

Pada perang aḥzab, Bani Quraiẓah (salah satu dari suku Yahudi) telah mengkhianati perjanjian dengan Rasulullah yang dibuat untuk seluruh penduduk kota Madinah termasuk suku mereka. Orang-orang Yahudi telah membantu pasukan ahzab untuk menyerang kaum Muslimin dari dalam kota Madinah.Setelah pasukan ahzab berhasil dikalahkan, Rasulullah pun bersabda "Siapa yang tunduk dan patuh, maka janganlah sekali-kali mendirikan salat ashar kecuali di bani Quraizah".SinyalemenRasulullah ini ditangkap dengan baik oleh shahabat sebagai sebuah isyarat untuk melakukan peperangan dengan Bani Quraizah.

\section{Membuat Peyimpangan dalam Islam}

'Abdullāh bin Saba', demikianlah namasalah seorang tokoh Yahudi yang berasal dari San'a sebuah kota di Yaman. Ia hidup pada masa khalifah 'Ali bin Abī Țālib, orang inilah yang menyuarakan bahwa pengganti Rasulullah sesungguhnya adalah 'Ali bukan Abu 
SAIDURRAHMAN: Sikap dan Pandangan Orang-orang Yahudi

bakar dan Umar, bahkan dia dengan lancangnya menyebut bahwa 'Ali sebagai Allah dan ia adalah seorang nabi. Ketika mendengar hal itu khalifah 'Ali kemudian mengusirnya. 'Abdullāh bin Saba' menghembuskan isu seolah-oleh mendukung Ali, padahal sesungguhnya ia menikam dari belakang. Begitulah kelicikan dari orang Yahudi. Mereka selalu menghembuskan nafas perpecahan, utamanya kaum Muslimin. Sudah menjadi watak dasarnya, kerusakan-demi kerusakan secara material dan mental spiritual kerap kali menjadi darah daging orang-orang Yahudi.

\section{Berubahkah Perilaku Orang-Orang Yahudi di Zaman Modern?}

Bangsa Yahudi adalah bangsa yang mengalami diaspora. ${ }^{19}$ Mereka tidak memiliki tempat tinggal secara pasti. Namun mereka merasa sebagai bangsa yang kemudian memiliki tanah air. Perasaan itu mengantarkan mereka pada pengusiran sekaligus pembunuhan tragis warga Muslim Palestina di jalur Gaza. Drama kemanusiaan yang cukup membuat setiap mata yang melihatnya menangis telah berlangsung selama puluhan tahun. Peritiwa itu terhitung sejak berdirinya Negara Israel tahun 1948. Dengan langkah cukup percaya diri dan mengabaikan seruan dunia, tentara Israel mengarahkan moncong senjata mereka untuk kemudian merenggut jiwa-jiwa suci yang tidak berdosa.

Di penghujung tahun 2008, rahim sejarah kembali berdarah. Perdamaian dan penghargaan terhadap hak azazi manusia dikhianati bangsa Yahudi. Nestapa kemanusiaan itu terjadi mulai Sabtu, 27 Desember 2008 sampai pertengahan Januari 2009 telah menewaskan sekitar 1300 warga sipil termasuk anak-anak dan perempuan, selebihnya luka-luka. Serangan Israel ke jalur Gaza dengan mengerahkan pesawat tempur jenis F-16, helikopter Apache dan tank telah membuat warga Palestina di jalur Gaza semakin tak berdaya.$^{20}$ Mungkinkah sikap tentara Israel ini terkait dengan upaya 
mereka menghapus bumi Palestina dari peta dunia? Mungkin saja pertanyaan "nakal" itu benar, mengingat sebelumnya bangsa Yahudi merupakan bangsa tanpa tanah air. Agresi mereka dapat diduga sebagai usaha keras untuk memasukkan Negara Israel ke peta dunia. Sebuah upaya yang mencerminkan kelicikanan dan haus kekuasaan.

Pembunuhan yang dilakukan orang-orang Israel di Palestina merupakan bukti nyata bahwa orang-orang Yahudi memiliki sinisme historis dengan umat Islam.Dari waktu ke waktu mereka mengisi rahim sejarah dengan darah dan air mata anak manusia yang tak berdosa. Sudah seharusnya umat Islam bangun dari mimpimimpinya, bersatu menghadapi anarkisme teologis dan sosial orangorang Yahudi. Kesadaran akan pentingnya mewujudkan persaudaraan umat Islam bukan hanya akan menghambat sinisme teologis dan sosial bangsa Yahudi itu. Lebih jauh, upaya itu merupakan tembok teologis dan sosial yang tidak bisa ditembus oleh senjata apapun dan kapanpun. Dengannya umat Islam akan mampu menghempang sikap dan pandangan negatif orang-orang Yahudi tersebut.

\section{Kehancuran Bangsa Yahudi}

Dr. Bassan Nahad Jarar, Intelektual Palestina, mengatakan bahwa Israel sesungguhnya sedang menunggu kehancurannya. Orang-orang Yahudi melakukan kesalahan sebanyak dua kali, dan mereka akan mendapat balasannya dari Allah. Jarar mendasari analisisnya melalui ayat berikut:

Dan telah Kami tetapkan terhadap Bani Israil dalam Kitab itu: "Sesungguhnya kamu akan membuat kerusakan di muka bumi ini dua kali dan pasti kamu akan menyombongkan diri dengan kesombongan yang besar".21

Menurut Jarar, orang-orang Yahudi tidak hanya melakukan kezaliman atas nama kemanusiaan, tapi juga melakukan berbagai kerusakan demi kerusakan yang terus dipertontonkan. Pembantaian 
SAIDURRAHMAN: Sikap dan Pandangan Orang-orang Yahudi

atas ribuan warga Palestina akhir 2008 dan awal 2009 merupakan kezaliman kedua, setelah sebelumnya pada zaman Babilonia mereka melakukan kezaliman yang pertama. Namun demikian, Allah senantiasa menepati janjinya. Orang-orang Yahudi di era Babilonia menerima hukuman yang amat berat, mereka dimusnahkan dan dihinakan sebagai hukuman yang pertama. ${ }^{22}$ Setelah wafatnya Nabi Sulaiman, bangsa Yahudi terpecah menjadi 12 suku, semuanya selalu membuat kerusakan. Akhirnya mereka diserang oleh bangsa Mesir, kemudian oleh Bangsa Assiria. Pada tahun 586 SM., Bangsa Babilonia menghancurkan Kerajaan Israel di bagian selatan. Setelah kehancuran tahun itu, tak ada lagi Negara atau kerajaan Israel. ${ }^{23}$ Sampai kemudian tahun 1948, PBB menetapkan wilayah Palestina sebagai Negara baru untuk Yahudi setelah terlunta-lunta pasca Perang Dunia II (1939-1945). Allah menjelaskan:

Maka apabila datang saat hukuman bagi (kejahatan) pertama dari kedua (kejahatan) itu, kami datangkan kepadamu hambahambakami yang mempunyai kekuatan yang besar, lalu mereka merajalela di kampung-kampung, dan itulah ketetapan yang pasti terlaksana. ${ }^{24}$

Jika kezaliman atas bangsa Palestina dianggap sebagai kezaliman kedua, kapan hukumannya akan datang? Jarar menjelaskan dengan menggunakan pendekatan "ta'wil mathemathic", bangsa Yahudi akan hancur pada tahun 2022. Jarar meyakini kehancuran itu akan pasti datangnya. Allah menegaskan bahwa akan datang hamba-hamba Allah yang tangguh dan mampu melakukan serangan dengan hebat. Siapakah hamba-hamba Allah yang hebat itu? Dalam konteks ini Jarar tidak merincinya.

\section{F. Penutup}

Sejarah telah merekam bahwa hubungan antara kaum Muslimin dengan orang-orang Yahudi selalu diwarnai ketegangan demi ketegangan. Tentu saja, ketegangan itu muncul akibat sikap 
tidak fair yang dilakukan orang-orang Yahudi dalam banyak aspek. Al-Quran dan hadis berikut fakta sejarah, sebagai sumber utama dalam tulisan ini, menginformasikan kepada kita bahwa sikap dan pandangan orang-orang Yahudi terhadap umat Islam cenderung peyoratif selain brutal. Kecaman demi kecaman bahkan kekerasan fisik kerap mereka tujukan kepada umat Islam. Hal itu terjadi dalam setiap waktu dan kesempatan, tidak hanya pada masa rasul-rasul sebelum Rasulullah Muhammad saw., pada masa beliau hingga masa kita pun sikap orang-orang Yahudi tidak pernah berubah.

Jika demikian faktanya, umat Islam harus menyadari bahaya eksistensi mereka di tengah-tengah pergaulan masyarakat dunia. Salah satu jalan yang harus ditempuh kaum Muslimin adalah mewujudkan ukhuwah islamiyah. Sekat-sekat yang selama ini memisahkan, untuk tidak mengatakan memecah, kaum Muslimin harus dilebur demi tugas bersama. Penderitaan kaum Muslimin di satu belahan dunia harus dianggap sebagai penderitaan bersama. Keyakinan itu harus diletakkan di atas segala perbedaan; sosial, budaya, politik, geografis dan sebagainya. Hanya dengan cara itu kaum Muslimin, dengan langkah mantap, dapat mengimbangi sikap dan pandangan sinis orang-orang Yahudi terhadap umat Islam. Janji Allah akan memberikan kehancuran kepada orang-orang Yahudi harus kita imani, namun upaya yang sistematis, terencana, manusiawi juga perlu kita terapkan. []

\section{Catatan Akhir}

1Dalam sejarahnya, Ibrahim memiliki dua orang istri, Siti Sarah dan Hajar.Dari Sarah lahir Ishaq dan perkembangan berikutnya melahirkan agama Yahudi dan Kristen, berkembang di Yerusalem. Sementara Siti Hajar melahirkan Ismail dan darinya lahir agama Islam yang dibawa Nabi Muhammad.Agama Islam berkembang di Mekah. Lihat, Ensiklopedi Tematis Dunia Islam, "Tradisi Monoteistik" Jakarta: 
PT. Ichtiar Baru Van Hoeve, 2007; Adel Allauche, "Arabian Religions", The Encyclopedia of Religion, Newyork: Macmillan, 1987.

2Untuk mengetahui agama Yahudi secara lebih lengkap dapat dibaca melalui karya; Huston Smith, Agama Manusia, Jakarta: Yayasan Obor Indonesia, 2004; Joesoef Sou'yb, Agama-Agama Besar Dunia, Jakarta: Pustaka Al Husna, 1983.

3Ismail Raji al-Faruqi dan Lois Lamya al-Faruqi, The Cultural Atlas of Islam, New York: Macmillan, 1986, h. 37-40.

${ }^{4}$ Rabbi Louis Jacob, We Have Reason to Believe; Some Aspects of Jewish Theology Examined in the Light of Modern Thought,London: Vallentine, Mitchel, tth.

5Lihat, "Jewish Views of Religious Pluralism", from Wikipedia, the free encyclopedia.

6 "The Chosen People", dikutip dari Jewish Encyclopedia.com.

${ }^{7}$ www.chosen people.com 1946.

${ }^{8}$ Aḥmad Musțafā al-Marāghī, Tafsīr al-Marāghī,Mesir: Al-Halabi,

${ }^{9}$ Kalimat-kalimat ini adalah kutukan dari Allah terhadap orangorang Yahudi yang berarti bahwa mereka akan terbelenggu di bawah kekuasaan bangsa-bangsa lain selama di dunia dan akan disiksa dengan belenggu neraka di akhirat kelak. Departemen Agama RI, AlQur'an dan Terjemahnya, Jakarta: Yayasan Penyelenggara Penterjemah/Pentafsir al-Qur'an, 1971, h. 171.

${ }^{10} Q S$. Al-Mā'idah [5]: 64.

${ }^{11} \mathrm{QS}$. al-Baqarah [ 2]: 40.

12Yang dimaksud ummi dalam ayat ini adalah orang-orang Arab.

${ }^{13}$ QS. Ali-Imran [3]: 75.

${ }^{14}$ Dalam ayat tersebut dijelaskan bahwa kata "lan" menunjukkan makna istimrar (terus menerus), dan kata itu diperuntukkan bagi orang-orang Yahudi.Tidak demikian halnya dengan orang-orang Nasrani. M. Quraish Shihab, Tafsir al-Mishbah,Vol. 1,Jakarta: Lentera Hati, 2006, h. 307-310.

${ }^{15}$ QS. al-Baqarah [2]: 120.

${ }^{16}$ QS. al-Mā'idah [5]: 82.

${ }^{17}$ Ahmad Syafii Maarif menyebutkan bahwa terorisme ada beberapa jenis, yaitu; terorisme yang dikendalikan oleh pribadipribadi dan terorisme yang dilakukan oleh Negara.Dalam konteks ini, orang-orang Yahudi Israel merupakan terorisme dalam bentuk kedua.Kerusakan yang ditimbulkannya boleh jadi lebih dahsyat 
daripada bentuk terorisme yang pertama. Lihat Ahmad Syafii Maarif, Mencari Autenstisitas dalam Kegalauan, Jakarta: PSAP, 2004, h. 4.

18Sebagai rujukan untuk kasus ini, penulis menggunakan buku Muhammad Husain Haikal, Hayatu Muhammad.

19Umar Anggara Jenie, "Akar Konflik Palestina Israel dalam Tinjauan Sejarah Kenabian", Makalah yang disampaikan di Pusat Studi Qur'an (PSQ), 4 Pebruari 2009.

20Majalah Sabili, No. 14 TH. XVI, 29 Januari 2009/3 Shafar 1430.

${ }^{21}$ QS. al-Isra' [17]: 4.

${ }^{22}$ Majalah Sabili, No. 14 TH. XVI, 29 Januari 2009/3 Shafar 1430, h. 42-47.

23Sami' bin Abdullah al-Maghluts, Atlas Sejarah Para Nabi dan Rasul; Mendalami Nilai-Nilai Kehidupan yang Dijalani Para Utusan Allah, Jakarta: Al-Mahira, 2008.

${ }^{24} \mathrm{QS}$. al-Isra' [17]: 5.

TEOLOGIA, VOLUME 25, NOMOR 2, JULI-DESEMBER 2014 


\section{DAFTAR PUSTAKA}

Allauche, Adel, “Arabian Religions”, The Encyclopedia of Religion. Newyork: Macmillan, 1987.

Departemen Agama RI, Al-Qur'an dan Terjemahnya, Jakarta: Yayasan Penyelenggara Penterjemah/ Pentafsir al-Qur'an, 1971.

Ensiklopedi Tematis Dunia Islam, "Tradisi Monoteistik", Jakarta: PT. Ichtiar Baru Van Hoeve, 2007.

Faruqi, Ismail Raji dan Lois Lamya al Faruqi, The Cultural Atlas of Islam, New York: Macmillan, 1986.

Haikal, Muhammad Husain, Hayat Muhammad, al-Qāhirah: Dār alMa'ārif, t.th.

Jacob, Rabbi Louis. We Have Reason to Believe; Some Aspects of Jewish Theology Examined in the Light of Modern Thought. London: Vallentine, Mitchel.

Jenie, Umar Anggara, "Akar Konflik Palestina Israel dalam Tinjauan Sejarah Kenabian", Makalah yang disampaikan di Pusat Studi Qur'an, 04 Pebruari 2009.

Lings, Martin, Muhammad: His Life Based on the Earliest Sources, London: Unwin Paperbacks, 1986.

Maarif, Ahmad Syafii, Mencari Autenstisitas dalam Kegalauan, Jakarta: PSAP, 2004.

Maghluts, Sami' bin Abdullah, Atlas Sejarah Para Nabi dan Rasul: Mendalami Nilai-Nilai Kehidupan yang Dijalani Para Utusan Allah, Jakarta: al-Mahira, 2008.

Majalah Sabili, No. 14 TH. Xvi 29 Januari 2009 / 3 Shafar 1430.

Marāghī, Ahmmad Musțafā, Tafsīr al-Marāghī,Mesir: al-Halabi, 1946.

Shihab, M. Quraish, Tafsir Al-Misbah Vol. 1 Jakarta: Lentera Hati, 2006.

Smith, Huston, Agama Manusia, Jakarta: Yayasan Obor Indonesia, 2004.

Sou'yb, Joesoef, Agama-Agama Besar Dunia, Jakarta: Pustaka Al Husna, 1983.

www.chosen people.com 